\title{
Thomas, Tristano e Isotta
}

\section{G. Matteo Roccati}

\section{(2) OpenEdition}

\section{Journals}

\section{Edizione digitale}

URL: http://journals.openedition.org/studifrancesi/9878

DOI: $10.4000 /$ studifrancesi.9878

ISSN: 2421-5856

\section{Editore}

Rosenberg \& Sellier

\section{Edizione cartacea}

Data di pubblicazione: 1 août 2017

Paginazione: 332

ISSN: 0039-2944

\section{Notizia bibliografica digitale}

G. Matteo Roccati, «Thomas, Tristano e Isotta», Studi Francesi [Online], 182 (LXI | II) | 2017, online dal 18 octobre 2017, consultato il 06 janvier 2021. URL: http://journals.openedition.org/studifrancesi/9878 ; DOI: https://doi.org/10.4000/studifrancesi.9878

\section{Questo documento è stato generato automaticamente il 6 janvier 2021.}

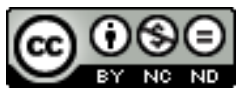

Studi Francesi è distribuita con Licenza Creative Commons Attribuzione - Non commerciale - Non opere derivate 4.0 Internazionale. 


\title{
Thomas, Tristano e Isotta
}

\author{
G. Matteo Roccati
}

\section{NOTIZIA}

THOMAS, Tristano e Isotta, revisione del testo, traduzione e note a cura di Francesca Gambino, Modena, Mucchi, 2014, 200 pp.

1 L'introduzione (pp. 5-30) traccia una rapida sintesi delle nostre conoscenze (la leggenda e gli episodi salienti nelle diverse fonti, i frammenti conservati del Tristan di Thomas, dati e ipotesi su autore e datazione, metrica, lingua). Segue l'edizione (testo di riferimento Marchello-Nizia, 1995, rivisto sui manoscritti) con a lato la traduzione italiana. Ogni frammento è preceduto da una breve presentazione, a piè di pagina apparato critico e note al testo. Bibliografia thomasiana di riferimento alle pp. 179-197. 